IZA DP No. 4396

Better Means More: Property Rights and

High-Growth Aspiration Entrepreneurship

Saul Estrin

J ulia Korosteleva

Tomasz Mickiewicz

September 2009 


\title{
Better Means More: Property Rights and High-Growth Aspiration Entrepreneurship
}

\author{
Saul Estrin \\ London School of Economics \\ and IZA \\ Julia Korosteleva \\ University College London \\ Tomasz Mickiewicz \\ University College London
}

\section{Discussion Paper No. 4396 \\ September 2009}

\author{
IZA \\ P.O. Box 7240 \\ 53072 Bonn \\ Germany \\ Phone: +49-228-3894-0 \\ Fax: +49-228-3894-180 \\ E-mail: iza@iza.org
}

\begin{abstract}
Any opinions expressed here are those of the author(s) and not those of IZA. Research published in this series may include views on policy, but the institute itself takes no institutional policy positions.

The Institute for the Study of Labor (IZA) in Bonn is a local and virtual international research center and a place of communication between science, politics and business. IZA is an independent nonprofit organization supported by Deutsche Post Foundation. The center is associated with the University of Bonn and offers a stimulating research environment through its international network, workshops and conferences, data service, project support, research visits and doctoral program. IZA engages in (i) original and internationally competitive research in all fields of labor economics, (ii) development of policy concepts, and (iii) dissemination of research results and concepts to the interested public.
\end{abstract}

IZA Discussion Papers often represent preliminary work and are circulated to encourage discussion. Citation of such a paper should account for its provisional character. A revised version may be available directly from the author. 
IZA Discussion Paper No. 4396

September 2009

\section{ABSTRACT \\ Better Means More: Property Rights and High-Growth Aspiration Entrepreneurship*}

This paper contrasts the determinants of entrepreneurial entry and high-growth aspiration entrepreneurship. Using the Global Entrepreneurship Monitor (GEM) surveys for 42 countries over the period 1998-2005, we analyse how institutional environment and entrepreneurial characteristics affect individual decisions to become entrepreneurs and aspirations to set up high-growth ventures. We find that institutions exert different effects on entrepreneurial entry and on the individual choice to launch high-growth aspiration projects. In particular, a strong property rights system is important for high-growth aspiration entrepreneurship, but has less pronounced effects for entrepreneurial entry. The availability of finance and the fiscal burden matter for both.

JEL Classification: D23, D84, G21, J23, J24, K11, L26, P51

Keywords: high-growth aspiration entrepreneurship, entrepreneurship, start-ups, property rights

Corresponding author:

Saul Estrin

Department of Management

London School of Economics

Houghton Street

London WC2A 2AE

United Kingdom

E-mail: S.Estrin@Ise.ac.uk

\footnotetext{
* The authors thank Paul Reynolds for sharing the consolidated Global Entrepreneurship Monitor (GEM) Adult Population Survey Data Set for 1998-2005 and Gian Fazio for assistance with merging this dataset with macro indicators. We are grateful to Zoltan Acs, Oleh Havrylyshyn, Philipp Koellinger, Wim Naudé, David Smallbone, Paul Reynolds, Gerald Roland, László Szerb, Friederike Welter, the participants of the London's Imperial College and UCL workshops on entrepreneurship, of the annual ASSA/ACES conference in San Francisco and University of Staffordshire seminar for comments, criticism and discussion.
} 


\section{Introduction}

In this paper, we contrast the determinants of individual decisions to become an entrepreneur and of aspirations to start up a high-growth business. We examine how various dimensions of the institutional environment, such as formal and informal financing, property rights and the degree of fiscalism, as well as the individual characteristics of entrepreneurs, such as their network capital and attitudes to risk, determine both the entrepreneurial decision to create a new firm and the growth ambitions of the new entrepreneurs. Our framework generates hypotheses that distinguish between the factors leading people to choose between becoming entrepreneurs who remain self-employed or form micro-enterprises with few people employed, and factors leading them to aspire to create firms of significant scale, able to employ a larger number of workers in the future. ${ }^{2}$ These factors include institutional features and the characteristics of the entrepreneurs themselves. We test our hypotheses using the Global Entrepreneurship Monitor (GEM) 1998-2005 surveys, which provide a large scale cross-country cross-individual dataset containing over 500,000 observations comprising 44 countries and at least 2,000 individuals in each country.

Entrepreneurship is increasingly seen as a vital force in economic development (Baumol 1990; Wennekers and Thurik 1999; Audretsch and Thurik 2004; Minniti et al. 2005; Minniti and Lévesque 2008). Entrepreneurs contribute to economic growth through generating, disseminating and applying innovative ideas; increasing competition and providing diversity among firms; enhancing economic efficiency and productivity (Cohen and Klepper 1992; Audretsch and Thurik 2004; Minniti et al. 2005). They are also an important engine for job creation, being responsible for anything from one-third to 70 per cent of job creation in the economy ${ }^{3}$ (Birch 1987; Storey 1994; Kirchhoff 1994; Westhead

\footnotetext{
${ }^{2}$ Hereafter, by high-growth aspiration entrepreneurial activity we mean nascent entrepreneurs (as defined in the GEM project, see Figure 1) who expect to create ten jobs or more in five years' time.

${ }^{3}$ The mortality rate of new and small businesses is higher than for larger firms, so that job destruction figures for start-ups may be also high (Acs 1998; Aldrich 1999). However, even when controlled for this, the net effect remains positive (Autio 2005).
} 
and Cowling 1995; Acs 1998; OECD 1998; Fölster 2000; Acs and Armington 2004). To understand the determinants of entrepreneurship, entrepreneurs' personal characteristics have been studied closely by researchers (Aidis et al. 2007; Aidis et al. 2008a; Grilo and Thurik 2004; 2005; Grilo and Irigoyen 2005; Ardagna and Lusardi 2008). In this research along with socio-demographic characteristics of entrepreneurs such as age, gender, education and past working experience, the effects of entrepreneurial perceptions and attitudes has also been explored. Recent studies emphasize the impact of specific entrepreneurs' traits, skills, and motivation factors, including goals, locus of control perceptions and self-efficacy (see for instance Harper 2003; Baum and Locke 2004).

Recognising cross-country heterogeneity in entrepreneurship, a growing number of empirical studies have centred on the importance of institutional settings for entrepreneurship, using either aggregate cross country or individual data. In particular, sound property rights have been argued to be a significant basis for entrepreneurial activity (Johnson et al, 2002, Aidis et al, 2009). Informal financing is also considered to be an important driver of early-stage entrepreneurial activity (Bates 1997; Bygrave et al. 2003; Casser 2003; Huyghebaert 2001; Korosteleva and Mickiewicz 2008). Such research analyses either the determinants of cross-country prevalence rates of entrepreneurial activity (Van Stel et al. 2007), or focuses on explaining an individual's decision to become an entrepreneur (Blanchflower and Oswald 1998, Blanchflower et al. 2001; Grilo and Thurik 2005; Grilo and Iriguen 2006; Aidis et al. 2009), but seldom combine both individual level and country level determinants.

A related literature focuses on the determinants of venture growth (Davidsson 1989; Baum et al. 2001; Becchetti and Vergata 2002; Baum and Locke 2004; Delmar et al. 2003), growth expectations (Wiklund et al. 2003; Aidis and Mickiewicz 2006) and the link between growth expectations and actual growth (Wiklund and Shepherd 2003; Aidis et al. 2008c). This provides strong support for the existence of a positive link between entrepreneurs' growth aspirations and actual growth, justifying the importance of studying aspirations; in particular when these are high-growth aspirations.

However, only limited empirical research has been undertaken on what determines high-growth aspiration entrepreneurial activity. Terjesen and Szerb (2008) investigate determinants of growth aspirations in nascent, young and 
established businesses using cross-country GEM data. They find that while prevalence of entrepreneurial entry is high in developing economies, higher job growth aspirations are typical for developed countries. Autio $(2005,2007)$ provides insights about cross-country and world regional patterns of a highgrowth aspiration entrepreneurial activity, its associations with national entrepreneurial environment, and individual characteristics of high-growth aspiration entrepreneurs, but falls short of providing testable implications regarding the determinants of high-growth aspiration entrepreneurship. Bowen and De Clercq (2008) analyse the impact of the institutional environment on the allocation of entrepreneurial effort toward high-growth activities. Their study is a pioneering work on how various institutional arrangements determine a highgrowth aspiration entrepreneurial activity, upon which we build. However, they use aggregate level data so their results may be subject to an endogeneity bias, given the possible reverse causality between the prevalence of high-growth entrepreneurship and institutional variables. Second, they estimate their models of high-growth aspiration entrepreneurship without reference to the decision to become an entrepreneur in the first place. In our study we address both issues.

Overall, our contribution can be summarised as follows. First, our study attempts to distinguish which institutions matter the most for explaining, on one hand, entrepreneurial entry restricted to self-employment or micro-enterprises, and on the other hand, the high-growth aspirations entry. In particular, we argue that more developed institutions enable more sophisticated forms of economic activity, namely high-growth aspiration entrepreneurship. Thus, for example, weak property rights do not necessarily hinder entrepreneurship, because informal arrangements and social networks may substitute for it, but high-growth aspiration entrepreneurship does benefit from more developed formal institutions. Second, we design our empirical models as a series of nested probit specification, which leads to robust estimates of both types of entry. Third, we use the GEM data set that contains rich individual-level information on entrepreneurs and combine it with information about country level institutional features. This addresses the potential endogeneity (simultaneity) bias noted above, because a country level variable cannot be affected by a single individual level characteristic. In particular, following North (1990) we take the property rights system as a fundamental characteristic of institutional quality. We find 
strong property rights to be of particular importance for individual decisions to choose high-growth aspiration entrepreneurship, whereas they tend to play a less pronounced role in explaining the decision to start a new micro-enterprise or selfemployment.

The paper proceeds as follows. The next section discusses theoretical issues pertaining to the determinants of entrepreneurs' decision to set up highgrowth aspiration ventures. Section 3 describes the data and the methodology. Empirical results follow in Section 4. Finally, Section 5 presents conclusions and policy implications.

\section{Determinants of High-Growth Aspiration Entrepreneurship: Theory}

A well-functioning business environment is likely to provide incentives to entrepreneurs in pursuing market opportunities for setting up new ventures and generating new jobs (North 1990, 1994; Baumol 1990, 1993; Djankov et al. 2002; Davidsson and Henrekson 2002; Harper 2003; Bowen and De Clercq 2008), while a weak institutional environment is an impediment to entrepreneurship (Johnson et al. 1999, 2000; McMillan and Woodruff 2002; Davidsson and Henrekson 2002; Aids et al. 2008). The quality of the institutional environment affects the allocation of entrepreneurial efforts among its various uses (Baumol $1990,1993,2005)$ and the potential of new firms to generate jobs is likely to vary with the institutional context.

Personal traits, competencies, motivation and cognition have been increasingly advocated to distinguish entrepreneurs from other individuals and to explain entrepreneurial strategies (Parker 2004; Aidis et al. 2007; Aidis et al. 2008a; Ardagna and Lusardi 2008; Korosteleva and Mickiewicz 2008). Facing an uncertain environment where additional information can only be acquired at a higher cost, individuals tend to adopt alternative cognitive strategies (DellaVigna, 2007). Cognitive factors, defined by Harper (2003:36) as the "individual's agency beliefs," affect entrepreneurial alertness to opportunities. More specifically, they comprise a "locus of control (or contingency expectations) and beliefs about self efficacy (or competence expectations)" which imply that the more individuals are 
convinced that certain outcomes are dependent upon certain actions and the more they are confident about their skills and capabilities, the more they are alert to new opportunities. While the entrepreneurial locus of control is largely affected by the institutional environment, self-efficacy is dependent on individual characteristics of entrepreneurs, including their socio-economic backgrounds, attitudes and perceptions. More specifically, self-efficacy may be enhanced through the acquisition of certain skills and knowledge. Thus, Aidis and Mickiewicz (2006) find that entrepreneurs' 'learning by doing' attributes, acquired through previous working experience or additional entrepreneurial experience, are positively related to growth aspirations. An increasing number of empirical studies examine the impact of entrepreneurial traits on venture growth (Baum and Locke 2004; Aidis and Mickiewicz 2006). Baum and Locke (2004) find positive direct effects of goals, growth aspirations and self-efficacy for venture growth and indirect effects through interaction with other factors such as passion for work, tenacity and resource skill.

We therefore expect not only institutional factors, but also entrepreneurs' individual characteristics to play an important role in explaining high-growth aspiration entrepreneurial activity. Our framework integrates institutional theory and the approach which stresses individual psychological traits of entrepreneurs and self-efficacy to study the choice of entrepreneurial strategies. Below we discuss each of these theoretical dimensions and postulate their likely importance for either or both entrepreneurship and high-growth aspiration entrepreneurship.

Drawing on the theoretical literature (North 1990, 1994; Baumol 1990, 1993; 2005) and the considerable body of empirical work discussed below we identify the three institutional dimensions which are likely to influence high-growth expectations entrepreneurship: (1) the protection of property rights; (2) the scale of the state as captured by the fiscal dimension; (3) the supply of finance (i.e. supply of formal finance and the prevalence of informal funding).

\subsection{Protection of Property Rights}

Strong property rights have been argued to exercise a fundamental positive effect on all economic activity. For entrepreneurship, it is important that the property rights guarantee the status quo and also include the 'find and keep' component, which is essential for the aspects of entrepreneurship related to 
discovery, innovation and creation of new resources (Harper 2003). Acemoglu and Johnson (2005) show that property rights institutions have pronounced effects on investment, financial development and long-run economic growth. Aidis's et al. (2009) empirical account reveals that among various institutional indicators, the property rights system plays pivotal role in determining entrepreneurial activity, especially in developing countries. Johnson et al. (2002) provide evidence that weak property rights discourage entrepreneurs to reinvest their retained profits into business.

While we expect that strong property rights are likely to encourage both entrepreneurial self-employment and micro-enterprise type of entry, we expect them to be particularly important for high-growth aspiration entrepreneurship. The latter implies both larger scale and (typically) more sophistication in economic activity; therefore, it tends to be more contract-intensive and to rely more on social contacts that go beyond the "family and friends" circle of trust. In addition, larger ventures are subject to higher risk of expropriation where property rights are not protected against arbitrariness of administration. Thus while weak property rights may not discourage all entrepreneurial activity, they may discourage larger and more complex forms of entrepreneurship.

\subsection{Size of the Government}

Secondly, we consider the impact of the state on entrepreneurial activity. In general, we would argue that a larger state sector will militate against entrepreneurial activity. Taxes and welfare provision may affect entrepreneurial entry via their direct impact on expected returns to entrepreneurial activity and its opportunity cost. High and increasing marginal level of taxes may weaken incentives for entrepreneurship by reducing potential gains. Moreover, a burdensome tax system (Batra et al. 2003; Aidis and Mickiewicz 2006), and one that works against capital income and benefits debt financing relative to equity financing (Davidsson and Henrekson 2002), has been identified as restraining firm growth. Parallel to this, high levels of welfare support provide alternative sources of income and may therefore reduce the net expected return to entrepreneurship. Taken together, this implies that entrepreneurial activity may be inversely related to the size of the state sector. Moreover, the disincentive effects seem likely to impact disproportionally on high growth entrepreneurs. 


\subsection{Finance}

Restrictions on the supply of finance have long been recognised as a major impediment to entrepreneurship (Stanworth and Gray 1991; Storey 1994; Beck et al. 2005; OECD 2006). Lack of credit history and shortage of collateral distinguish new firms from established ones and, given small scale of entrepreneurial projects, financial institutions find it costly to monitor small firms. The situation is aggravated by the perception that start-ups have higher risk of failure. Taken together, entrepreneur's access to external finance is restricted and the cost of finance is raised (Huyghebaert and Gucht 2007, Korosteleva and Mickiewicz 2008), though, these constraints may be alleviated in more developed financial markets through the wider allocation of savings to potential investment projects and the facilitation of risk management (Levine 1997; Levine et al. 1999). Financial development is found to have significant and positive effects for entrepreneurial entry (Van Stel et al. 2007; Aidis et al. 2008a) and for firm financing and growth (Kumar et 2002; Demirgüç-Kunt and Maksimovic 1998, Beck et al. 2005). Moreover, a wider supply of finance is particularly beneficial for small firms compared to the larger ones (Becchetti and Trovato 2002; Beck et al. 2005; Grilo and Irigoyen 2006).

However, start-ups use only moderate levels of formal external financing, typically relying disproportionally on their own equity and informal financing (Bates 1997; Bygrave 2003; Huyghebaert 2001). For new entrepreneurial projects, 'internal governance' structures based on personal trust within the social groupings based on family and local friends (Harper 2003) may be seen as superior to costly monitoring by formal financial institutions (see also: Korosteleva and Mickiewicz 2008). But, the scale of informal finance is limited and often insufficient for larger projects. Moreover, informal financiers may be reluctunt to concentrate their risk on small numbers of large projects. Accordingly, Bygrave (2003) argues that while informal financing is accessible to all entrepreneurs, formal finance plays a more significant role for 'star' firms, such as high-growth entrepreneurs, high-technology firms and export-oriented small firms. We therefore expect that informal financing will have more pronounced effects on self-employment and micro-enterprise type of entry than on high-growth aspiration entrepreneurship. In contrast, we expect the size of the formal financial 
system will be positively related to high-growth aspiration entrepreneurship, but less so to low-growth entrepreneurial entry.

\subsection{Network capital, experience and personal cognitive determinants} of the entrepreneurial alertness

Self-efficacy "arises from the cognitive appraisal of one's capabilities"; it is important in explaining an individual's alertness to entrepreneurial opportunities and may be enhanced by social learning (Harper 2003). Business networks are found to play an important role for entrepreneurs via social learning using role models (Minniti et al. 2005) and in assisting them to access resources for business creation (Aldrich et al. 1987; Djankov 2006; Nanda and Sorensen 2007; Aidis et al. 2008a; 2008b). Network capital also facilitates entrepreneurs' access to finance (Aldrich et al 1987, Johannisson 2003) and is often regarded as an intangible asset that can be used to overcome difficulties arising from failure of formal institutions.

For example, previous entrepreneurial experience can make subsequent entry more likely, because it enhances self-efficacy through the "direct mastery experience (learning by doing) and vicarious experience (learning by seeing)" (Harper 2003, p. 46). On the other hand, an existing business ownership implies that the opportunity cost of new involvement is high, and the latter would be chosen only if its expected net present value is significant, as is the case with high-growth aspiration projects. Hence we expect being an owner of an established business to be positively associated with high-growth aspiration entrepreneurship, but not with low-growth entrepreneurial entry.

\section{Data and Methodology}

\subsection{Sample Description}

In our study we utilize the data collected through the GEM adult population surveys in 1998-2005 that covers 44 countries worldwide ${ }^{4}$. The data consists of

\footnotetext{
${ }^{4}$ For countries included into the 1998-2005 datasets and year coverage see Reynolds (2005).
} 
representative samples of at least 2,000 individuals in each country. The samples are drawn from the working age population that allows avoiding the selectivity bias that often confounds other studies, which focus on the existing entrepreneurs only. GEM surveys were completed through phone calls and through face-to-face interviews in countries, where low density of the telephone network could create a bias. National datasets are harmonised across all countries included in the survey ${ }^{5}$.

The GEM data gives the opportunity to examine cross-national entrepreneurial activity, while capturing the widest possible range of business creation activities. Respectively, we can distinguish between (a) individuals who intend to create a new venture, (b) who are in the process of establishing a new firm (or start-ups, classified as nascent entrepreneurs) ${ }^{6}$, (c) currently operating young firms (under 3.5 years) ${ }^{7}$, and (d) other owners-managers of established businesses. For the purpose of this study we will focus on start-ups, and distinguish between high-growth aspiration and no-growth oriented ventures.

The GEM dataset provides unique information on entrepreneurs' personal characteristics, ranging from standard socio-demographic-economic characteristics to more specific entrepreneurial traits, perceptional and attitudinal variables. In the next sub-section we discuss variable definitions and measurements in more detail.

\footnotetext{
5 For more details of the sampling procedure see Reynolds et al. (2005, 2008).

${ }^{6}$ According to the GEM criteria, start-ups or nascent entrepreneurs are defined as individuals between 18-64 years old, showing some action towards setting up a new business whether fully or partly owned. They also must not yet have paid any wages or salaries for more than three months (for summary of this definition see Figure 1).

7 These two categories constitute together total entrepreneurial activity (Reynolds et al. 2005).
} 


\subsection{Variable definitions and measurement}

We utilise a set of various country-level measures of institutional environment along with individual-level variables. We can safely use aggregatelevel explanatory variables without being concerned about simultaneity bias: the individual decision of a potential entrepreneur should not affect country-level institutions or economic development. This gives us some comparative advantage over Bowen and De Clercq's (2008) study, whose model may be subject to endogeneity bias.

There is no universally accepted set of measures of institutional quality. So far, many scholars have largely relied on what is commonly referred to as institutional outcome variables (Glaser et al. 2004). These include survey indicators provided by the International Country Risk Guide (e.g. a measure of risk of expropriation), the World Bank measures of Governance effectiveness; the World Bank's Doing Business indicators; and the Heritage Foundation / Wall Street Journal indices. In this study, we rely on the Heritage Foundation - Wall Street Journal 'Economic Freedom' Indicators, World Bank 'World Development Indicators', and the aggregate peer effects (prevalence rates) based on the GEM adult population survey, calculated by the authors. More specifically, we use the Heritage Foundation 'Property Rights' and 'Fiscal Freedom" measures (see: Beach and Kane 2008) ${ }^{8}$.

The Heritage Foundation / Wall Street Journal index of property rights, has broad coverage and has been commonly used by other scholars (Acemoglu and Johnson 2005; Aidis et al. 2007). It shows the degree of protection of individuals' private property rights by law on books and through its enforcement, and the extent to which private property is protected from expropriation (Beach and Kane 2008). To achieve better distributional characteristics for our variables (which are bound from both below and above) we transform the original indices into odds. ${ }^{9}$

For the size of the government, we use the Heritage Foundation 'Fiscal Freedom Index' that is calculated on the basis of both the tax burden in terms of the tax rate on individual and corporate income and the overall amount of tax

\footnotetext{
${ }^{8}$ World Bank Doing Business data is an obvious alternative, but it does not cover the time period of our study.

${ }^{9}$ For the transformation we use the following formula: [Index/(100-Index)]. The index implies that the stronger the property rights, the higher is the transformed indicator.
} 
revenue as a proportion of GDP (Beach and Kane 2008). Again, we transform the variable into odds to improve its distributional characteristics.

The availability of formal finance is defined as the ratio of domestic credit to private sector to GDP, obtained from the World Bank 'World Development' Indicators. This measure has been commonly used in previous studies (Klapper et al. 2006; Aidis et. al 2009). To capture the supply of informal funding we introduce the prevalence rate of informal institutional investors, derived on the basis of our GEM data by taking the average percentage of respondents who invested in someone else's start-up in the past three years in each country-year sub-sample. Finally, we use the GEM-defined variables to represent business ownership. We also capture social network effects by introducing a dummy variable which shows if the respondent knows other entrepreneurs.

\subsection{Control variables}

In addition to the institutional variables, the set of explanatory variables includes macroeconomic indicators and personal characteristics of entrepreneurs.

\subsubsection{Macroeconomic Development Indicators}

To capture the level of economic development and cyclical effects we introduce a measure of economic development proxied by per capita GDP (at purchasing power parity) and GDP annual growth rate (obtained from the World Bank World Development Indicators). The link between entrepreneurial activity and per capita GDP has been widely acknowledged (Carree et al. 2002, Wennekers et al. 2005). As per capita GDP increases, the rate of entrepreneurial activity falls and that may be explained by the emergence of economies of scale. As income stability can be provided by large domestic firms, many individuals prefer employment to self-employment at this stage ${ }^{10}$. We expect a positive

\footnotetext{
${ }^{10}$ However, entrepreneurial activity could surge again after passing a certain threshold in highincome countries, being affected positively by the accumulation of individual savings and economic environment favourable to exploitation of new opportunities. In our specifications we also introduced per capita GDP squared to test this hypothesis of non-monotonicity, and we found some supporting evidence, however the model became overspecified andthe Wald statistics difficult to obtain.
} 
relationship between per capita GDP and high-potential entrepreneurship, whereas it is likely to be negative for entrepreneurial entry, reflecting likely push effects in low income countries, consistent with Terjesen and Szerb (2009).

We introduce the GDP annual growth rate variable to reflect a cyclical economic performance (see also Koellinger and Thurik 2009). We expect that in a period of recession individuals are less likely to launch ambitious projects. We also include a set of various personal characteristics of entrepreneurs which are found to play an important role for entrepreneurial entry and their strategic choice.

\subsubsection{Human capital}

Previous GEM-based research shows that individuals with higher educational attainment are more likely to start a business (Minnitti et al. 2005b) and direct their efforts towards high-growth activities (Autio 2005). We use the GEM data on the age of individuals to construct two dummy variables, measuring first post-secondary and higher education jointly and second an incremental effect of higher education only.

\subsubsection{Other personal characteristics of entrepreneurs}

A number of research studies confirm that such socio-demographic features of entrepreneurs as age, gender and work status are significant determinants of entrepreneurial entry. Previous GEM studies suggest that middle-aged persons are more likely to start a business (Reyonolds et al. 1999; Minnitti et al. 2005b).

Entrepreneurial activity is found to vary significantly with gender. Being a male is more likely to drive up the rates of entrepreneurship (Minnitti et al. 2005a; Grilo and Thurik, 2005; Estrin and Mickiewicz, 2009).

We also introduce a dummy variable for the individual experience of having been a business angel in the past and control for "fear of failure" (Ardagni and Lasardi, 2008).

\subsubsection{Dependent variables}

We utilize four nested dependent variables, coded as dummies. The first, which identifies start-up activity as defined in Figure 1, enters our first equation. 
The second narrows down entrepreneurial entry to projects which are expected to create any incremental employment; that is, we exclude self-employment $(38 \%$ of startup projects in our data). The third indicator relates to high-growth aspiration entrepreneurial entry with 1 denoting those who have intentions to launch high-growth oriented projects (expecting to create ten or more jobs). This represents $18 \%$ of all startups. Finally, to investigate robustness of our results, we narrow down our definition of high growth aspiration entry only to projects with expected employment of twenty people or more. This category represents $8 \%$ of all startups.

\{Figure 1 about here\}

Tables 1-2 provide definitions of all explanatory and dependent variables respectively and report descriptive statistics.

\{Tables 1 and 2 about here\}

\subsection{Methodology}

In our empirical investigation we do not separate the decision to enter from expectations related to employment creation by new projects but rather stress the simultaneous nature of both. This is reflected in the definition of the dependent variables outlined above. Moreover, the nested nature of these variables (each subsequent category is a subset of the previous one) enables us to estimate the determinants of each category of entrepreneurial entry separately, without concern for cross-equation correlation. This comes at a cost of efficiency of our estimations: separating the entry decision and the growth aspirations could lead to more significant estimates ${ }^{11}$. In all our estimations we control for annual time

\footnotetext{
${ }^{11}$ We also estimated two stage probit-probit selection models but this was open to criticism on two grounds: First, the separation of the entry decision and growth expectations could be questioned as problematic, second, alternative choices of selection variables for the first (entry) equation were criticised. We therefore opt for the more conservative estimation strategy just outlined, though the two-stage model results were somewhat stronger. We also investigated the possibility of applying multiple probit, where both high-aspiration entrepreneurship and lowaspiration entrepreneurship are pitched against inactivity (lack of entry). However, the results of
} 
effects. We experimented with the full set of country fixed effects, but the probit estimator collapses without producing credible Wald statistics. The country fixed effects problem arises because the GEM dataset is unbalanced with many countries appearing just once or twice over time. In addition, the introduction of fixed country effects while retaining institutional measures is highly problematic, as the cross sectional variation of the latter is washed out leaving only timevariation which for institutional indicators constists predominantly of measurement error (as changes in institutions are often registered with random time lag and imprecisely). However, our reported standard errors are clustered on country-year groups allowing for within-group correlation. Without this correction, given the large number of observations, all our significance levels will look artificially much better. In addition, we also utilise information in the GEM dataset which attributes population-based weighting to each observation. All our estimations apply this weighting. ${ }^{12}$

\section{Empirical Results and Discussion}

The correlation matrix for the institutional variables is presented in Table 3 and the estimation results are in Table 4.

$\{$ Table 3-4\}

We find that while the Property Rights variable has no significant impact on entry in general, it emerges as the most important determinant of high-growth aspiration entrepreneurship. The positive and statistically significant impact of this indicator is robust, as confirmed by the results of alternative specifications (with either ten or twenty people threshold level of employment). The contrast between the results for entrepreneurial entry and for high-growth entrepreneurship may be explained by the fact that for low-scale ventures new entrepreneurs rely on informal institutions and localised trust to build self-efficacy necessary for successful entry. However, the larger-scale projects require more reliance on

Small-Hsiao tests rejected this model, indicating that there is strong interdependence in the three alternatives.

${ }^{12}$ We are grateful to Paul Reynolds for drawing our attention to this issue. 
formal, impersonal institutions and the stability they may offer. Therefore, weak property rights become a binding constraint for entrepreneurial development. Weak protection of property rights may also affect negatively the motivation of entrepreneurs to expand their businesses: they may start new ventures, but restrict themselves to small scale projects.

In contrast with property rights, we find that the size of state sector affects both general entrepreneurial entry and high-growth entry negatively, but we detect no differential impact when comparing those two categories. Similarly, the size of the formal financial sector is conducive to both high-growth aspiration entrepreneurship and entrepreneurial entry in general. This result becomes more interesting when we consider the effects of the formal financial sector supply jointly with the prevalence of informal financing. The latter is found to play a far more significant role for general entrepreneurial entry. When we compare the marginal probit effects (as reported in Table 4), the impact of supply of informal finance on general entrepreneurial entry is ten times stronger that its impact on entry with ten or more jobs expected to be created. We interpret these results as an indication that the entrepreneurs with high growth ambitions are more likely to rely on formal external financing, given the larger scale of their projects. More generally, this contrast illustrates how informal institutions may to some extent substitute for defficient formal institutional environment: in particular social capital embeded in informal finance provided by friends and family supports entrepreneurial entry. However it is insufficient as a factor enhancing highpowered projects.

Our study also confirms that there is some difference in the impact of being an owner of any other existing businesses between entrepreneurial entry and high-growth entrepreneurship. While being an owner of existing business has a negative effect on both entrepreneurial entry and on high-expectation entry, the marginal effect is about twenty five times weaker when we focus on entry with twenty or more jobs expected to be created. This suggests that entrepreneurs involved in current business are more likely to start new high-growth ventures than low-growth ventures. This relationship between high-growth aspiration entrepreneurship and 'being an owner of established business' may suggest the existence of some important learning effects resulting in serial entrepreneurship. 
Consistently with this, the effects of network capital are also captured through the variable representing the embeddedness in social networks as proxied by 'knowing other entrepreneurs' variable. These effects are consistently significant across all specifications employed in this study. We also find that a greater selfperceived risk aversion is likely to discourage both entrepreneurial entry and high-growth entrepreneurial activity.

Other controls largely follow expectations. We find that per capita GDP is negatively related to both entrepreneurial entry and to 'high growth' projects. Impact of GDP growth is insignificant. The tax burden is negatively and statistically significantly associated with both entrepreneurial entry and with highgrowth aspiration entrepreneurship. This result is consistent with the view that high taxes and burdensome tax regulation are costly for small firms (Winiecki, 2003).

The results also show interesting patterns in terms of entrepreneurs' sociodemographic and other individual characteristics. Age is related to entrepreneurial entry. The relationship between age and entrepreneurial entry is quadratic with the likelihood of entering entrepreneurship is rising up to the point when entrepreneurs reach their middle age, and falling after that. The previous studies also find that middle-aged are more likely to enter entrepreneurship (Reynolds et al. 1999; Minniti et al. 2005b). Interestingly, while being in employment has positive impact both on entrepreneurial entry and on highgrowth aspiration entrepreneurship, the marginal effect in the latter case is much smaller. Similar effects relate to higher education. In contrast, while being male makes both entry and high-growth aspiration entrepreneurship more likely, the effect on the latter is far stronger. Marginal positive effect of being a male is about three to four times stronger with respect to high growth entry than with respect to general entry measure.

Previous experience as business angel that can also serve as a proxy for accumulated own financial resources exerts positive effects on both entrepreneurial entry and on high-growth aspiration entrepreneurship, albeit the second seems weaker. Perceptional and attitudinal variables characterising entrepreneurs are also important for both entry and for high-growth aspiration entrepreneurship, as represented by the lack of fear of failure. 


\section{Conclusions}

The key message resulting from our findings is that more sophisticated institutions are correlated with more advanced forms of economic activity, represented in our case by high-growth aspiration entrepreneurship. The latter enhance efficiency and foster economic development. In particular, weak property rights do not prevent individuals from becoming entrepreneurs. However, they do discourage them from expanding their ventures and from hiring other people. Similarly, while informal finance plays important role for entry, it matters far less for high-powered entrepreneurial projects. 


\section{References:}

Acemoglu, D. and S. Johnson (2005) "Unbundling Institutions", Journal of Political Economy, 113, 943-995.

Acs, Z. (1998) The New American Evolution. US Small Business Administration Office of Economic Research, June.

Acs, Z., J, and C., Armington (2004) "Employment Growth and Entrepreneurial Activity in Cities", Regional Studies, 38(8), November, pp. 911-27.

Aidis, R. (2005) "Entrepreneurship in Transition Countries: A Review", CSESCE Working Papers, No. 61.

Aidis, R. and T., Mickiewicz (2006) "Entrepreneurs, Expectations and Business Expansion: Lessons from Lithuania", Europe-Asia Studies, 58(6), pp. 855880.

Aidis, R., Estrin, S. and Mickiewicz, T. (2008a) "Institutions and Entrepreneurship Development in Russia: A Comparative Perspective", Journal of Business Venturing, 23, pp. 656-672.

Aidis, R., J. Korosteleva and T. Mickiewicz (2008b) "Entrepreneurship in Russia" in L. Dana, I. Welpe, V. Ratten and M. Han (eds.) Entrepreneurship and Internationalisation of SMEs in Asia (Cheltelham: Edward Elgar), forthcoming.

Aidis, R., T., Mickiewicz and A., Sauka (2008c) "Why are Optimistic Entrepreneurs Successful? An Application of the Regulatory Focus Theory", William Davidson Institute Working Paper Series, No. 914.

Aidis, R., S. Estrin and T. Mickiewicz (2009) Entrepreneurial Entry: Which Institutions Matter?, Discussion Paper 7278, London: CEPR.

Aldrich, H., B. Rosen and W. Woodward (1987) The Impact of Social Networks on Business Funding and Profit. Frontiers of Entrepreneurship Research (Wellesley, MA: Babson College).

Alrdrich, H. (1999) Organisations Evolving, London: Sage.

Ardagna, S. and A. Lusardi (2008) "Explaining International Differences in Entrepreneurship: the Role of Individual Characteristics and Regulatory Constraints", NBER Working Paper, No. 14012.

Audretsch, D. and M., Keilbach (2004) "Entrepreneurship Capital and Economic Performance", Regional Studies, 38(8), November, pp. 949-59.

Audretsch, D. and R., Thurik (2004) "A Model of the Entrepreneurial Economy", International Journal of Entrepreneurship Education, 2(2), pp. 143-66. 
Autio, E. (2007) Global Entrepreneurship Monitor: 2007 Global Report on HighGrowth Entrepreneurship. London Business School and Babson College: London, U.K., and Babson Park, MA.

Autio, E. (2005) Global Entrepreneurship Monitor: 2005 Report on HighExpectation Entrepreneurship. London Business School and Babson College: London, U.K., and Babson Park, MA.

Autio, E., P., Arenius, and H., Wallenius (2000) Economic Impact of gazelle firms in Finland. Helsinki University of Technology, ISIB Working Papers 2000-3.

Bates, T. (1997) "Financial Business Creation: The Case of Chinese and Korean Immigrant Entrepreneurs", Journal of Business Venturing, 12, 109-124.

Baum, J., R. and E., Locke (2004) "The Relationship of Entrepreneurial Traits, Skill, and Motivation to Subsequent Venture Growth", Journal of Applied Psychology, 4, 587-598.

Baum, J., R., E., Locke and Smith (2001) "A Multidimensional Model of Venture Growth", Academy of Management Journal, 44(2), 292-303.

Baumol, W. (1990) "Entrepreneurship: Productive, Unproductive, and Destructive", Journal of Political Economy, 98 (5, Part I), October, pp.893-921.

Beach, W. and Kane, T. (2008) "Methodology: Measuring the 10 Economic Freedoms" in Holmes, K., E., Feulner,, and M., O'Grady (eds.) 2008 Index of Economic Freedom, The Heritage Foundation: Washington, pp.39-55.

Becchetti, L. and G., Trovato (2002) "The Determinants of Growth for Small and Medium Sized Firms. The Role of the Availability of External Finance", Small Business Economics, 19, pp. 291-306.

Beck, T., A., Demirgüç-Kunt and V., Maksimovic (2005) "Financial and Legal Constraints to Growth: Does the Firm Size Matter?", The Journal of Finance, Vol. LX, No.1 February 2005.

Bennett, J. and Estrin, S., "Regulatory Barriers and Entry in Developing Economies", IZA Working Paper, 2006.

Birch, D. (1987) Job generation in America, The Free Press: New York.

Bowen, H.P. and De Clercq, D. (2008) "Institutional Context and Allocation of Entrepreneurial Effort", Journal of International Business Studies, forthcoming. Blanchflower, D., and A., Oswald (1998) "What makes an entrepreneur?", Journal of Labor Economics, 16 (1), pp. 26-60. 
Blanchflower, D., A., Oswald and A., Stutzer (2001), "Latent Entrepreneurship across Nations", European Economic Review, 45(4-6), pp. 680-691.

Brüderl, J. and P., Preosendörfer (2000) "Fast Growing Businesses: Empirical Evidence from a German Study", International Journal of Sociology, 30, pp. 45-70.

Bygrave, W. (2003) "Financing Entrepreneurs and their Ventures" in Reynolds, P., W. Bygrave and E. Autio (eds.) Global Entrepreneurship Monitor 2003 Global Report, Kansas City: Kauffman Center for Entrepreneurial Leadership at the Ewing Mario Kauffman Foundation.

Bygrave, W., M. Hay, E. Ng and P. Reynolds (2003) "A Study of Informal Investing in 29 Nations Composing the Global Enterprise Monitor", Venture Capital: An International Journal of Entrepreneurial Finance, Vol. 5, pp. 101116.

Carree, M., A., van Stel, R., Thurik and S., Wennekers (2002) "Economic Development and Business Ownership: An Analysis Using Data of 23 OECD Countries in the Period 1976-1996", Small Business Economics, 19, pp.271290.

Choi, J.P., and Thum M. (2005) "Corruption and the shadow economy", International Economic Review, 46(3), pp. 817-36.

Cohen, W. and S., Klepper (1992) "The Tradeoff Between Firm Size and Diversity in the Pursuit of Technological Process", Small Business Economics, 4(1), March, pp. 1-14.

Cohen, W. and D., Levinthal (1989) "Innovation and learning: the two faces of R\&D, Economic Journal, 99, pp. 569-96.

Damijan, J.P, Knell, M. Majcen B. and M. Rojec (2003) The role of FDI, R\&D accumulation and trade in transferring technology to transition countries: evidence from firm panel data for eight transition countries, Economic Systems 27 (2003)189-204.

Davidsson, P. (1989) "Entrepreneurship and after? A study of growth willingness in small firms, Journal of Business Venturing, 4, pp. 211-226.

Davidsson, P. and Henrekson,M. (2002) 'Determinants of the prevalence of startups and high-growth firms', Small Business Economics, 19(2): 81-104. 
De Backer, K., and Sleuwaegen, L. (2003) 'Does foreign direct investment crowd out domestic entrepreneurship', Review of Industrial Organization, 22(1): 67-84.

DellaVigna, S. (2007), 'Psychology and Economics: Evidence from the Field', NBER Working Paper Series, Working Paper 13420, Cambridge MA: National Bureau of Economic Research.

Delmar F., P., Davidsson, W., Gartner (2003) "Arriving at High-Growth Firm", Journal of Business Venturing, 18(2003), pp. 189-216.

Demirgüç-Kunt, A. , I., Love, and V., Maksimovic (2006) “ Business Environment and the Incorporation Decision", Journal of Banking and Finance, 30, pp. 2967-2993.

Demirgüç-Kunt, A. and V., Maksimovic (1998) “Law, Finance, and Firm Growth”, Journal of Finance 53, pp. 2107-2137.

Dixit, 2004. Lawlessness and Economics (Princeton and Oxford: Princeton Univerisity Press).

Djankov, S., R., La Porta, F., Lopez-De-Silanes, and A. Shleifer (2002) "The Regulation of Entry", Quarterly Journal of Economics, CXVII (1), pp. 1-36.

Djankov, S., Y., Qian, G., Ronald, and E. Zhuravskaya (2006) "Entrepreneurship in China and Russia Compared", Journal of the European Economic Association, 4(2-3),pp. 353-365.

Estrin, S., K., Meyer, and M., Bytchkova (2006) "Entrepreneurship in Transition Eocnomies", in Casson, M., A., Basu, B., Yeung and N., Wadesdon (eds.) The Oxford Handbook in Entrepreneurship, Oxford University Press: Oxford.

Estrin, S. and T. Mickiewicz (2009) "Do Institutions Have a Greater Effect on Female Entrepreneurs?", World Bank, mimeo, available at <<http://siteresources.worldbank.org/INTGENDER/Resources/3360031240628924155/EstrinMickiewicz..pdf>>

Fölster, S. (2000) "Do Entrepreneurs Create Jobs?”, Small Business Economics, 14(2), March, pp. 137-48.

Grilo, I., and R., Thurik (2005) "Latent and Actual Entrepreneurship in Europe and the US: Some Recent Developments", International Entrepreneurship and Management Journal, 1(4), pp. 441-459.

Grilo, I., and J., Irigoyen (2006) "Entrepreneurship in the EU: To wish and not to be”, Small Business Economics, 26(4), pp. 305-318. 
Hall, R. and S. Woodward (2008), "The Burden of the Nondiversifiable Risk of Entrepreneurship", NBER Working Paper No 14219.

Harper, D. (2003) "Foundations of Entrepreneurship and Economic Development", Abingdon: Routledge.

Huyghebaert, N. and L. Van de Gucht (2007) "The Determinants of Financial Structure: New Insignts from Business Start-ups", European Financial Management, Vol. 13, No.1 pp. 101-133.

Huyghebaert, N. (2001) "The Capital Structure of the Business Start-ups: Determinants of Initial Capital Structure", Review of Banking Finance", 2, pp. 84-88.

Javorcik, B., S. (2004) Does Foreign Direct Investment Increases the productivity of domestic firms? In search of spillovers through backward linkages, American Economic Review, June, Vol. 94, No.3, pp.605-627.

Jonhanisson, B. (2000) "Networking and Entrepreneurial Growth" in D. Sexton and H. Lawrence (eds) The Blackwell Handbook of Entrepreneurship. Blackwell: Oxford, pp. 368-386.

Johnson, P. (2004) "Differences in Regional Firm Formation Rates: A Decomposition Analysis", Entrepreneurship Theory and Practice, Vol. 28(5), pp. 431-445.

Johnson, P, J., McMillan and C. Woodruff (1999) Contract Enforcement in Transition, EBRD Working Paper, No. 45.

Johnson, P, J., McMillan and C. Woodruff (2000) "Entrepreneurs and the Ordering of Institutional Reform", Economics of Transition, 8(1), pp. 1-36. Johnson, S., J., McMillan and C. Woodruff (Dec., 2002) "Property Rights and Finance", The American Economic Review, Vol. 92, No.5, pp. 1335-1356.

Kirchhoff, B. A. (1994), Entrepreneurship and Dynamic Capitalism: The Economics of Firm Formation and Growth, Praeger: Westport, Conn.

Kirzner, I. (1973), Competition and Entrepreneurship, Chicago: University of Chicago.

Kirzner, I. (1979), Perception, Opportunity and Profit, Chicago: Univerisity of Chicago.

Klapper, L., L., Laeven, and R., Rajan (2006) "Entry Regulation as a Barrier to Entrepreneurship", Journal of Financial Economics, 82, pp. 591-629. 
Koellinger, P. and A. Thurik (2009) 'Entrepreneurship and the Business Cycle', Discussion Paper No. 032/3, Rotterdam: Tinbergen Institute.

Korosteleva, J. And T. Mickiewicz (2008) "Finance and Entrepreneurial Entry", CSESCE Working Paper No 96, Centre for the Study of Economic and Social Change in Europe, UCL.

Kumar, K., R., Rajan and L., Zingales (1999) "What Determines Firm Size?", National Bureau of Economic Research Working Paper, No. 7208.

La Porta, R., F., Lopez-de-Silanes, A., Shleifer and Vishny, R.W. (1998) "Law and Finance", Journal of Political Economy, 106, pp. 1113-1155.

La Porta, R., F., Lopez-de-Silanes, A., Shleifer and Vishny, R.W. (2000) "Investor Protection and Corporate Governance", Journal of Financial Economics, 58, pp. 1-25.

La Porta, R., F., Lopez-de-Silanes and A., Shleifer, A. (2008) "The Economic Consequences of Legal Origins", Journal of Economic Literature, 46(2), pp. 285-332.

Levine, R., 1997. Financial development and economic growth: views and agenda. Journal of Economic Literature, 35 (June), pp. 688-726.

Levine, R., Loayza, N. and Beck, T., 1999. Financial intermediation and growth. Policy Research Working Papers, 2059 (February). Washington D.C.: World Bank.

McMillan, J. and C., Woodruff (2002) "The Central Role of Entrepreneurs in Transition Economies", Journal of Economic Perspectives, 16(3), pp. 153170.

Minniti, M., P., Arenius and N., Langowitz (2005a) Global Entrepreneurship Monitor: 2004 Report on Women and Entrepreneurship, Centre for Women's Leadership at Babson College: London Business School.

Minniti, M., W. Bygrave and E. Autio (2005b) Global Entrepreneurship Monitor: 2005 Executive Report, Wellesley, MA: Babson College.

Minniti, M. and Lévesque, M. (2008 forthcoming) "Recent Development in the Economics of Entrepreneurship", Journal of Business Venturing.

Nanda, R. and J. Sorensen (2007) "Peer Effects and Entrepreneurship", Harvard Business School Working Paper, No. 08-051. 
Navaretti, G. B., and A. J. Venables (2004) Multinational Firms in the World Economy, Princeton University Press, Princeton, chapter 10: Policy implications and effects, pp. 241-276.

North, D. (1990) Institutions, Institutional Change and Economic Performance, Cambridge University Press: Cambridge.

North, D. (1994) "Economic performance over time", American Economic Review, 84, pp. 359-368.

OECD (1998) Fostering Entrepreneurship, The OECD Jobs Strategy, OECD: Paris.

OECD (2006) The SME Financing Gap: Theory and Evidence, Vol. 1. OECD Publishing.

Parker, S.C., The Economic of Self-Employment and Entrepreneurship, Cambridge, UK: Cambridge University Press, 2004.

Reynolds, P., M., Hay and S., Camp (1999) Global Entrepreneurship Monitor: 1999 Executive Report, Babson College, London Business School and Kauffman Foundation.

Reynolds, P., N., Bosma, E., Autio, S. Hunt, N., De Bono, A., Servais, P., LopezGarcia and N., Chin (2005) "Global Entrepreneurship Monitor: Data Collection Design and Implementation 1998-2003, Small Business Economics, 24, pp. 205-231.

Reynolds, P. and D., Hechavaria (2008) Global Entrepreneurship Adult Population Data Sets: 1998-2003. Codebook and Data Set Description, ICPSR Project 20320.

Schumpeter, J. (1934) The Theory of Economic Development (Cambridge, MA: Harvard University Press).

Smallbone, D. \& F. Welter. 2001. 'The Distinctiveness of Entrepreneurship in Transition Economies.' Small Business Economics 16, pp. 249-62.

Stanworth, M. and C. Gray (1991) Bolton 20 years on - the small firm in the 1990s. Paul Chapman Publishing: London.

Storey, D. (1994) Understanding the Small Business Sector. Routledge: New York.

Terjesen, S. and L. Szerb (2008) 'Dice Thrown from the Beginning? An Empirical Investigation of Firm Level Growth Expectations', Estudios de Economía 35(2), pp. 153-178. 
Van Stel, A., D., Storey and R., Thurik (2007) "The Effect of Business Regulations on Nascent and Young Business Entrepreneurship", Small Business Economics, 28, pp. 171-186.

Verbeek, M. (2000) A Guide to Modern Econometrics, John Wiley \& Sons: New York.

Wennerkers, S. and R. Thurik (1999) "Linking Entrepreneurship and Economic Growth", Small Business Economics, 13(1), August, pp.27-55.

Wennekers, A., A., van Stel, A., Thurik and P., Reynolds (2005) "Nascent Entrepreneurship and Economic Development", Small Business Economics, 24, pp.293-309.

Westhead P. and M., Cowling (1995) "Employment change in independent owner-managed high technology firms in Great Britain", Small Business Economics, 7(2), pp. 111-140.

Wiklund, J., P., Davidsson and F., Delmar (2003) "What do they think and feel about growth? An expectancy-value approach to small business managers attitudes toward growth", Entrepreneurship Theory and Practice, 27(3), pp. 247-270.

Wiklund, J. and D., Shepherd (2003) "Aspiring for and Achieving Growth: The Moderating role of Resources and Opportunities", Journal of Management Studies, 40, pp. 1919-1941.

Winiecki, J. (2003) "The Role of the New Entrepreneurial Sector in Transition and Economic Performance in Light of the Successes in Poland, the Czech Republic and Hungary", Problems of Economic Transition, 45, 11, pp. 6-38.

Wooldridge, J. (2002), Econometric Analysis of Cross Section and Panel Data (Cambridge, MA and London, UK: MIT Press). 
Figure 1: GEM Classification of Nascent Entrepreneurial Activity (Startups)

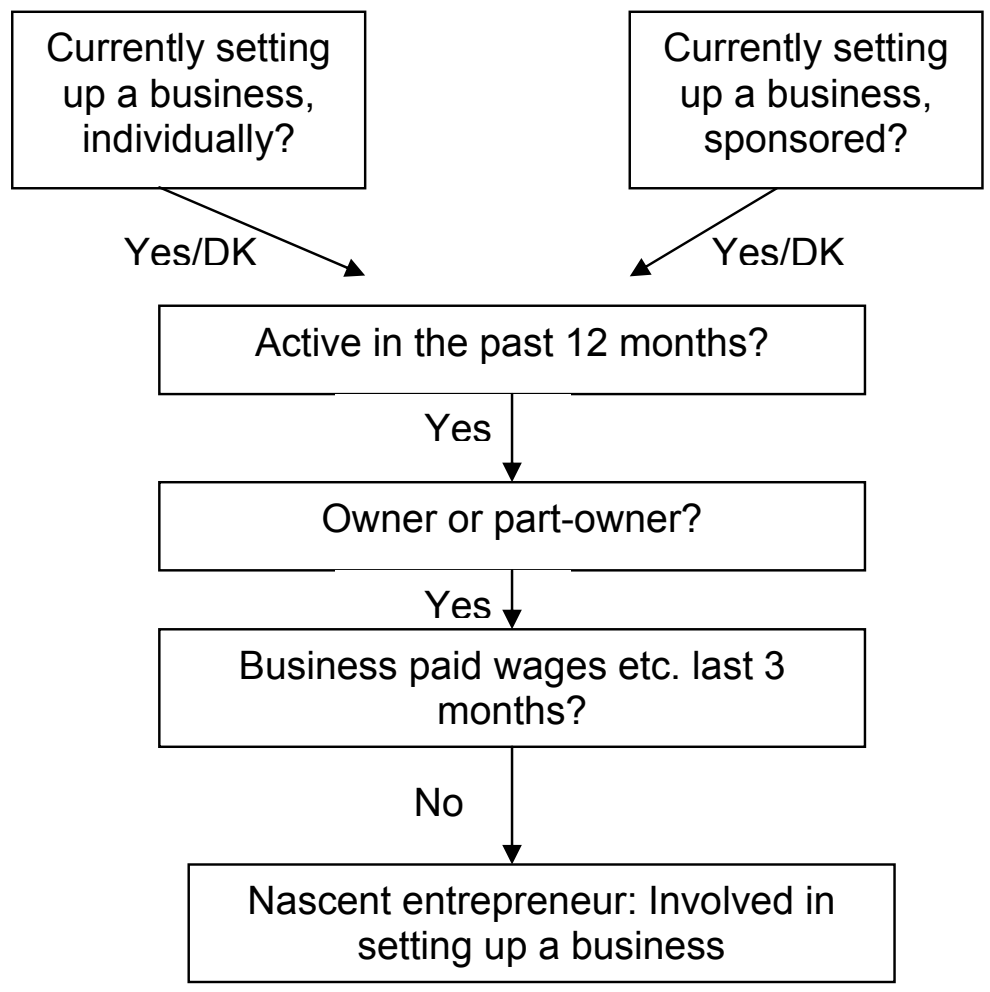


Table 1a: Descriptive statistics and definitions of explanatory variables:

\section{Business environment \& macroeconomic variables}

\begin{tabular}{|l|l|c|c|c|}
\hline Variable & Definition & Mean & S.D. & No of obs. \\
\hline Property rights & $\begin{array}{l}\text { 'Property Rights index, } \\
\text { transformed in odds } \\
\text { Index/(100-Index)]; higher } \\
\text { value denotes stronger } \\
\text { property rights (Heritage F.) }\end{array}$ & 6.22 & 3.60 & 589,579 \\
\hline Fiscal freedom & $\begin{array}{l}\text { 'Fiscal Freedom' Index, } \\
\text { transformed into odds } \\
\text { Index/(100-Index)]; higher } \\
\text { value denotes higher fiscal } \\
\text { burden (Heritage Foundation) }\end{array}$ & 1.82 & 1.50 & 551,376 \\
\hline $\begin{array}{l}\text { Formal finance } \\
\text { as \% of GDP }\end{array}$ & $\begin{array}{l}\text { Ratio of credit to private sector } \\
\text { to GDP, prercentage (WB) }\end{array}$ & 110.6 & 46.77 & 602,287 \\
\hline $\begin{array}{l}\text { Informal finance } \\
\text { prevalence }\end{array}$ & $\begin{array}{l}\text { Informal investors prevalence, } \\
\text { percentage }\end{array}$ & 2.73 & 1.68 & 607,184 \\
\hline GDP per capita & $\begin{array}{l}\text { GDP per capita at purchasing } \\
\text { power parity, constant at 2000 } \\
\text { \$USD (World Bank) }\end{array}$ & $26,584.8$ & $10,009.4$ & 607,184 \\
\hline GDP growth & $\begin{array}{l}\text { Annual GDP growth rate, } \\
\text { percentage (World Bank) }\end{array}$ & 3.05 & 2.43 & 607,184 \\
\hline
\end{tabular}

Table 1b: Descriptive statistics and definitions of explanatory variables: Personal Characteristics

\begin{tabular}{|c|c|c|c|c|}
\hline Age & $\begin{array}{l}\text { The exact age of the } \\
\text { respondent between } 14 \text { and } 99 \\
\text { at time of interview }\end{array}$ & 42.98 & 16.56 & 607,184 \\
\hline Male & 1=male, zero otherwise & .47 & .50 & 607,181 \\
\hline Employment & $\begin{array}{l}\text { 1=respondent is either in full or } \\
\text { part time employment, } 0 \\
\text { otherwise }\end{array}$ & .51 & .50 & 588,567 \\
\hline $\begin{array}{l}\text { Post-secondary } \\
\& \quad \text { higher } \\
\text { education }\end{array}$ & $\begin{array}{l}\text { 1=respondent has a post } \\
\text { secondary or higher education } \\
\text { attainment, } 0 \text { otherwise }\end{array}$ & .65 & .48 & 562,431 \\
\hline $\begin{array}{l}\text { Higher } \\
\text { education }\end{array}$ & $\begin{array}{l}\text { 1=respondent has a higher } \\
\text { education attainment }\end{array}$ & .22 & .41 & 562,431 \\
\hline $\begin{array}{l}\text { Current owner } \\
\text { of business }\end{array}$ & $\begin{array}{l}1=\text { current owner/manager of } \\
\text { business, } 0 \text { otherwise }\end{array}$ & .05 & .22 & 607,184 \\
\hline Business angel & $\begin{array}{l}1=\text { business angel in past three } \\
\text { years, } 0 \text { otherwise }\end{array}$ & .03 & .16 & 605,793 \\
\hline Fear of failure & $\begin{array}{l}\text { 1=respondent belives that the } \\
\text { fear of failure would not } \\
\text { prevent him/her from starting a } \\
\text { business }\end{array}$ & .33 & .47 & 472,230 \\
\hline $\begin{array}{l}\text { Knows other } \\
\text { entrepreneurs }\end{array}$ & $\begin{array}{l}\text { 1=personally } \\
\text { entrepreneurs in past two } \\
\text { years, zero otherwise }\end{array}$ & .36 & .48 & 465,480 \\
\hline
\end{tabular}

Source for Table 1b variables: GEM 1998-2005 consolidated dataset 
Table 2: Descriptive statistics and definitions of dependent variables

\begin{tabular}{|c|c|c|c|c|}
\hline $\begin{array}{l}\text { Categories of } \\
\text { entrepreneurial entry: }\end{array}$ & Definition & Mean & S.D. & No of obs \\
\hline $\begin{array}{l}\text { Nascent } \\
\text { entrepreneurship }\end{array}$ & $\begin{array}{l}1=\text { respondent is engaged in } \\
\text { startup activity, zero otherwise }\end{array}$ & .034 & .18 & 607,184 \\
\hline $\begin{array}{l}\text { Nascent } \\
\text { entrepreneurship } \\
\text { excluding self- } \\
\text { employment }\end{array}$ & $\begin{array}{l}1=\text { respondent is engaged in } \\
\text { startup activity expecting to } \\
\text { employ other people in } 5 \text { years } \\
\text { time or earlier, zero otherwise }\end{array}$ & .024 & .15 & 603,020 \\
\hline $\begin{array}{l}\text { High-growth } \\
\text { aspiration nascent } \\
\text { entrepreneurship: } \\
\geq 10 \text { employees }\end{array}$ & $\begin{array}{l}1=\text { respondent is engaged in } \\
\text { startup activity and expects to } \\
\text { create } 10 \text { or more jobs in } 5 \\
\text { years time, zero otherwise }\end{array}$ & .007 & .084 & 603,020 \\
\hline $\begin{array}{l}\text { High-growth } \\
\text { aspiration nascent } \\
\text { entrepreneurship: } \\
\geq 20 \text { employees }\end{array}$ & $\begin{array}{l}1=\text { respondent is engaged in } \\
\text { startup activity and expects to } \\
\text { create } 20 \text { or more jobs in } 5 \\
\text { years time, zero otherwise }\end{array}$ & .003 & .059 & 603,020 \\
\hline
\end{tabular}

Source: Variables constructed on the basis of GEM 1998-2005

Table 3: Correlation matrix for institutional variables

\begin{tabular}{|c|c|c|c|c|c|c|}
\hline & $\begin{array}{l}\text { Property } \\
\text { rights }\end{array}$ & $\begin{array}{l}\text { Fiscal } \\
\text { burden }\end{array}$ & $\begin{array}{c}\text { Formal } \\
\text { finance as } \\
\% \text { of GDP }\end{array}$ & $\begin{array}{l}\text { Informal } \\
\text { finance } \\
\text { prevalence }\end{array}$ & $\begin{array}{c}\text { GDP } \\
\text { per } \\
\text { capita }\end{array}$ & $\begin{array}{l}\text { GDP } \\
\text { growth }\end{array}$ \\
\hline Property rights & 1.00 & & & & & \\
\hline Fiscal burden & -0.21 & 1.00 & & & & \\
\hline $\begin{array}{l}\text { Formal finance } \\
\text { as } \% \text { of GDP }\end{array}$ & 0.54 & -0.21 & 1.00 & & & \\
\hline $\begin{array}{c}\text { Informal finance } \\
\text { prevalence }\end{array}$ & -0.01 & 0.02 & -0.12 & 1.00 & & \\
\hline $\begin{array}{c}\text { GDP } \\
\text { per capita }\end{array}$ & 0.75 & -0.30 & 0.61 & -0.10 & 1.00 & \\
\hline $\begin{array}{l}\text { GDP annual } \\
\text { growth rate }\end{array}$ & -0.17 & 0.23 & -0.13 & 0.18 & -0.19 & 1.00 \\
\hline
\end{tabular}

Source: GEM 1998-2005 


\section{Table 4: Estimation results: probit marginal effects}

dependent

$\begin{array}{lrlll}\text { explanatory variables: } & \mathrm{dF} / \mathrm{dx} & & \text { Std. Err. } \\ \text { age } & 0.001278 & * * * & 0.000387 \\ \text { age squared } & -0.00002 & * * * & 0.000005 \\ \text { male } & 0.01372 & * * * & 0.000947 \\ \text { in employment } & 0.007177 & * * * & 0.002026 \\ \text { education: post-sec\&higher } & 0.007629 & * * * & 0.001243 \\ \text { higher education } & 0.004054 & * * & 0.001389 \\ \text { current owner of business } & -0.00567 & * * * & 0.001694 \\ \text { business angel in last 3 y } & 0.033918 & * * * & 0.002802 \\ \text { knows other entrepreneurs } & 0.033042 & * * * & 0.002106 \\ \text { no fear of failure } & -0.01581 & * * * & 0.001021 \\ \text { GDP per capita (ppp) } & -0.00000 & * * * & 0.000000 \\ \text { GDP annual growth rate } & -0.00022 & & 0.000782 \\ \text { property rights } & 0.00037 & & 0.000412 \\ \text { fiscal freedom } & 0.003338 & * * * & 0.000633 \\ \text { credit to priv. sector /GDP } & 0.000106 & * * & 0.000034 \\ \text { informal finance prevalence } & 0.344734 & * * * & 0.060083 \\ \text { Number of observations } & 379131 & & \\ \text { Wald chi squared } & 3046.23 & * * * & \\ \text { Pseudo R2 } & 0.108 & & \\ \text { Log pseudolikelihood } & -56783.9 & & \\ & & & \end{array}$

start-up excl. self-empl.

\begin{tabular}{rll}
\multicolumn{1}{rl}{$\mathrm{dF} / \mathrm{dx}$} & & Robust \\
0.0008509 & $* * *$ & 0.000257 \\
-0.000014 & $* * *$ & 0.000003 \\
0.0112855 & $* * *$ & 0.000833 \\
0.0055638 & $* * *$ & 0.001576 \\
0.0053659 & $* * *$ & 0.00099 \\
0.0029988 & $* * *$ & 0.00084 \\
-0.002876 & $*$ & 0.001202 \\
0.024323 & $* * *$ & 0.002185 \\
0.0234634 & $* * *$ & 0.001549 \\
-0.010617 & $* * *$ & 0.000712 \\
-0.00000 & $* * *$ & 0.000000 \\
0.0001838 & & 0.000627 \\
0.0000117 & & 0.00028 \\
0.002077 & $* * *$ & 0.000461 \\
0.0000752 & $* * *$ & 0.000002 \\
0.23331 & $* * *$ & 0.035875 \\
376230 & & \\
2483.68 & $* * *$ & \\
0.1124 & & \\
-42867.6 & &
\end{tabular}

startup 10 jobs or more

Robust

$\begin{array}{rll}\mathrm{dF} / \mathrm{dx} & & \text { Std. Err. } \\ 0.000149 & * & 0.000072 \\ -0.6 & * * & 0.000001 \\ 0.004332 & * * * & 0.000305 \\ 0.001399 & * * * & 0.000354 \\ 0.002441 & * * * & 0.000397 \\ 0.001049 & * * & 0.000379 \\ -0.00056 & & 0.00041 \\ 0.008137 & * * * & 0.001194 \\ 0.007552 & * * * & 0.000633 \\ -0.00323 & * * * & 0.000273 \\ -0.00000 & * * * & 0.000000 \\ 0.000166 & & 0.000183 \\ 0.000285 & * * & 0.000093 \\ 0.000561 & * * * & 0.000129 \\ 0.000016 & * & 0.000006 \\ 0.034826 & * * & 0.011932 \\ 376230 & & \\ 1752.18 & * * * & \\ 0.12 & & \\ -16716.8 & & \end{array}$

startup 20 jobs or more

\begin{tabular}{rll}
\multicolumn{1}{rl}{$\mathrm{dF} / \mathrm{dx}$} & & Robust \\
0.00003 & & Std. Err. \\
-0.000 & + & 0.00004 \\
0.002004 & $* * *$ & 0.000000 \\
0.000517 & $* *$ & 0.000176 \\
0.001241 & $* * *$ & 0.000205 \\
0.000322 & + & 0.000178 \\
-0.00027 & & 0.000225 \\
0.00446 & $* * *$ & 0.000852 \\
0.003466 & $* * *$ & 0.000318 \\
-0.00155 & $* * *$ & 0.000172 \\
-0.000 & $* *$ & 0.000000 \\
0.00008 & & 0.00009 \\
0.000153 & $* *$ & 0.000055 \\
0.000153 & $* * *$ & 0.00006 \\
.00001 & $*$ & 0.000003 \\
0.0132 & $* *$ & 0.005922 \\
376230 & & \\
1101.77 & $* * *$ & \\
0.1206 & & \\
-8946.02 & &
\end{tabular}

Notes: ${ }^{* * *}$ significant at $0.001 ;{ }^{* *}$ significant at $0.01 ;{ }^{*}$ significant at $0.05 ;$ +significant at 0.1 ; annual dummies included but not reported; robust standard errors clustered on country-years; estimations with GEM population-based weighting. 